\title{
Alternative Theories, Pedagogy and Education for Fostering Creativity in a Diverse Global World
}

\author{
Gail E. Thomas \\ Soka University of America, Aliso Viejo, USA \\ Email: thomas@soka.edu \\ Received 4 May 2016; accepted 23 July 2016; published 30 July 2016
}

\begin{abstract}
Fostering creativity and social responsibility in children and youth are essential for more effectively addressing society's most pressing problems. This article proposes alternative pedagogy and methods for fostering creativity and enhancing teaching and learning for creativity. It emphasizes the importance of connecting the goals of teaching creative education to the broader goal of education for social and global responsibility. Two schools attempting to implement the latter are described.
\end{abstract}

Keywords

Fostering Creativity, Critical Pedagogy, Value Creation, Social Responsibility, Teachers

\section{Introduction}

Expanding creativity among children and youth is essential for advancing global society and solving its most pressing problems. This will entail: (1) re-examining and extending the concept of creativity [1] [2]; (2) employing more innovative, culturally diverse and progressive education and pedagogy [3]-[6]; and (3) implementing more teacher training and support [7]. This paper reviews some of the research on creativity and suggests alternative theories and methods for fostering creativity. It highlights the importance of directing the outcomes of teaching creative education to fostering greater social and global responsibility in children and youth. It concludes with examples of two schools attempting to foster creativity, social and global responsibility in students.

\section{Defining Creativity}

One of the challenges and pre-requisites in identifying and fostering creativity lies in defining it. It means different things to different people. For example, a former interpreter for the Dali Lama noted that in the Tibetan language there is no word for creativity [2]. In the $19^{\text {th }}$ Century, creativity was viewed as a rare attribute or talent among an exceptional and limited segment of the population. Research by some psychologists and biologists supported this view [8], [9] (p. 4; p. 20), [10]. 
Dr. Rosa Aurora Chavez-Eakle, Founder and Director of the Washington International Center for Creativity, defined creativity as the "generation of new things or new ideas, or the transformation of those previously existing” ([1], p. 4). Businessmen and Founders of Stanford University’s Hasso Plattner Institute of Design, Tom and David Kelly, argued that everyone has creative potential and that "creativity is a mindset; a way of thinking and a proactive approach to finding new solutions [2].” They maintained that believing in one's ability to create and having "creative confidence" lies at the heart of creativity and innovation for them.

Howard Gardner, a well-known American psychologist, defined creativity as "liberating human energy" expressed in various ways [11]. While his research and findings focused on human intelligence rather than creativity, his theory of multiple intelligence broadened the views regarding teaching, learning and assessing various aspects of children's capacity and creativity. Each child, according to Gardner, is unique with at least eight different domains of intelligences. He noted that these domains are not limited to the linguistic and mathematical ability or right brain cerebral functioning. They include emotional, social, musical, physical, ecological and visual intelligences.

Gardner's findings on multiple intelligences and the research by Eisner [12] and Chavez-Eakle [1] on creativity, extended the focus regarding creativity by taking it from a biological to an educational perspective, thus implying that it could be taught and learned. This highlighted the role of schools and teachers in fostering and enhancing creativity. In his research on fostering creativity, Yu-Sein Lin, Professor and researcher at the National Academy for Education Research in Taiwan, suggested three issues that school administrators and teachers must address in fostering and implementing creativity: (1) how to implement innovative educational practices that enhance student creativity; (2) how to make school environments stimulating, supportive and amenable to creative teaching and learning; and (3) how teachers can be encouraged and trained to be more open to creative ideas, more creative in their teaching and in valuing student agency and independence ([5], p. 149).

Yu-Sein Lin [5] formulated a three-part model of creative pedagogy as a general framework that school teachers and administrators might consider in attempting to address the latter three issues. The first part of his model depicted an authoritarian and traditional style of teaching that does not permit student autonomy or encourage critical thinking and creativity. The radical Brazilian educator, Paulo Freire [13] described this type of teaching and learning as educational banking wherein teachers deposit prescribed knowledge "into the brains of students” [13]. Students are passive recipients and repositories of knowledge based on this perspective.

Lin contrasted this traditional type of learning with his depiction of a more interactive and dual learning process between teacher and student. This aspect of his model represents a more democratic exchange between teacher and student where both are at times teacher and learner. This type of innovative and more democratic method fosters student autonomy and creative teaching and learning [5].

\section{Application of Critical Pedagogy in the Creative Arts}

Frank Abrams [14] proposed Paulo Freire’s [13] critical pedagogy as a method for teaching music education and supporting its goal of empowering students to become musicians. Freire developed this method of pedagogy to teach uneducated and largely rural adults (which he labeled "the oppressed") how to read. Freire viewed education as dialogue between teacher and student. He insisted that teaching and learning be empowering, transformative and rooted in the authentic lives and experiences of students.

By applying Freire's pedagogical approach to music education, Abrams believed that the potential of both students and teachers could be further developed. He stressed that an initial critical aspect in teaching music education begins with teachers asking four questions: Who am I? Who are my students? What might they become? What might we become together? After deeply reflecting upon and answering these questions, teachers should then be able to develop more flexible curricula and more student-centered class activities that: (1) engage students in problem solving and experimentation; (2) connect their experiences and perspectives to their lives and to the world of music; (3) provide opportunities for students to practice and demonstrate learned concepts; and (4) permit dialogue, reflections and assessments of possible transformations that occur for students and teachers [14]. Abrams found that as a result of applying Freire's pedagogical approach, students were more creative and engaged; and expressed greater appreciation and interest in music education. Teachers were also able to better recognize and take into consideration the learning styles of each student, and reinforce them in diverse ways ([14], p. 14). 


\section{Teachers as Ethnographers}

Educators applying Paulo Freire's [13] approach of critical pedagogy to education insist that teachers be familiar with their students, including their cultures and communities [3] [14]. This is important given the increasing diversity among students. Research reveals that teachers have limited experiences outside of their own communities and believe that they live in a world very different from most of their students [15]. Training teachers to become ethnographers has been suggested as a method for helping teachers to gain more direct and broader knowledge about their students [15]. Ethnography is a qualitative research approach that focuses on observations and attention to the context, artifacts and natural environments in which people live and interact. Individuals who become emic ethnographers do not hold themselves to be objective observers far remove from the people that they seek to understand. Instead, they become immersed in the communities they are in. They strive to learn from and understand the lives and perspectives of the individuals in these local environments. As a result they become "insiders", taking the role of participant observers; learning from various members in the community. Therefore, teachers trained asemic ethnographers may be better able to identify and foster creativity in their students as a result of becoming more familiar with and experiencing them in a more authentic context. This approach might also allow students to become more familiar with and connected to their teachers.

\section{Education Purpose and Teaching for Creativity}

A review of the literature and research offered various perspectives on the meaning and methods of fostering creativity. However, a remaining question of importance is: For what purpose should fostering creativity and creative education be directed? Responses to this question may vary depending upon perspectives and the different resources, needs and priorities of each country and culture. For example, given the persistent crisis in global youth unemployment, members of the United Nations Economic and Security Council [16] call for greater emphasis and educational investments in skills-based and vocational education [17]. However, social entrepreneurs like Yong Zhao ([18]; p. 5) and other business leaders [2] stress the importance of educating youth for social entrepreneurship and social responsibility. Social entrepreneurs are individuals in business ventures who use their skills and resources to find innovative ways to solve society’s most pressing problems. They incorporate social and global responsibility into their business.

Closely related to education for social responsibility is the philosophy of value creating pedagogy expounded by an early Japanese educator, Tsunesaburo Makiguchi. Observing the conditions of Japanese primary education during his day, Makiguchi described it as devoid of purpose and counter to the happiness and welfare of the students. He commented that it consisted of "little more than mental gymnastics and memorization of material unrelated to children's lives” ([19]; p. 48). Makiguchi therefore proposed a theory of value creation based on his belief that human happiness is the prime goal to which education should be directed.

Makiguchi defined happiness as "the state of existence in which individuals create value” in full” ([19]; p. 50). In full means that happiness is not some euphoric individual state of being. For Makiguchi, it is, "the state in which individuals are consciously and systematically engaged in creating value forself and others in the society in which they live ([19]; p. 51). Therefore, education should aim to foster students who seek to create value based on a "harmonious balance benefitting both self and society" ([19]; p. 51).

\section{Schools for Value Creation and Social Responsibility}

Brief descriptions are given of two schools whose philosophy, teaching and learning incorporate elements of value creation, social and global responsibility. The first, Soka University of America, is a private liberal arts college in Aliso Viejo, California. The word Soka means to create value and derives from Makiguchi's theory of value creation. The University's mission is to, "foster a steady stream of global citizens committed to living a contributive life.” Contributive life refers to value creation for self and others.

Students and teachers at Soka University meet in small classes and engage in extensive dialogue and project-based learning. Field trips and learning beyond the classroom are an integral part of the curriculum. The latter occurs through both local and international field-based term courses, and alternative Spring Break learning modules. Students are exposed to, and learn from citizens in local and global communities. To the extent that time and resources permit, students provide voluntary and requested assistance to community members during their field learning experiences. Student narratives, interviews, testimonies, self-reflective journals, and public exhibits provide a basis for assessing their learning and curricular goals and objectives. 


\section{High Tech High (HTH) Schools in San Diego: Product and Project-Based Oriented Learning}

High Tech High is part of an urban public school complex in San Diego, California. The school seeks to "prepare students for global competencies, connections and success in post-secondary education ([18]; p. 240) and to make useful products that will serve their community or broader society. This is achieved through project-based learning, design principles and student product production. Students are selected to attend High Tech High based on a lottery system. Teachers at High Tech High do not assign textbooks to students [18]. Instead, students write, produce and sell their own books. In addition, they make documentaries, films, music and video games. Teachers and school administrators give students the freedom and space to work, think, design, and to be creative. Students work independently on projects a large portion of the day, with teachers serving largely as facilitators, guides and mentors ([18], p. 192). Teachers at High Tech High employ innovative and nontraditional student assessments through informal face-to-face feedback and peer friendly reviews [20]. More formal assessments include rubrics created by teachers and students, and input by community members based on student public performances.

\section{Considerations for Further Study and Conclusions}

This paper suggested alternative educational pedagogies, methods and practices for enhancing creativity in education. However, research and observations were largely from a western perspective. Thus findings from other cultural perspectives are need to "shed additional light" on the subject matter. For example, extending the research to include the perspectives of indigenous cultures might provide new knowledge. Archibald and Dewar [21] illustrated the benefits of employing the creative arts for First Nation Inuit and Met is indigenous communities in healing programs in Canada.

Secondly, more detailed investigations regarding the status and methods of creative education in different types of schools might extend existing knowledge. The progressive and non-traditional schools affiliated with the International Democratic Education Network [4] may provide a unique source of inquiry. In addition, the traditional public and private schools in America and elsewhere may also provide a contrast and additional perspective on creative education. American private schools in general have been found to have more course offerings in the arts than public schools and more innovative and student-centered learning [22].

Lastly, it is important to capture the voices and perspectives of teachers regarding creative education. Current literature remains limited in this area. Therefore, formal and informal interviews, and detailed narratives may prove useful in capturing the views, challenges and needs of teachers regarding creative education. Previous research [7] indicated that teachers have limited understanding about creativity and teaching for creativity; and that they give more attention to creativity when it is required school policy. In her study, Craft [23] noted that while creative education was viewed as a "good thing” by teachers and school administrators, implementing it created dilemmas for teachers given tighter budget controls and constraints and frequent and changing mandates that impact curriculum requirements, teaching and learning. These demands on teachers, coupled with persistent challenges and worries regarding job security, adequate pay, and classroom resources, are additional issues that might impact teacher attitudes, perspectives and motivations regarding creative education and teaching for creativity.

\section{References}

[1] Chavez-Eakle, R. (2010) The Relevance of Creativity in Education. Johns Hopkins University New Horizons for Learning. http://education.jhu.edu

[2] Kelly, D. and Kelly, T. (2013) Creative Confidence. Crown Business Publishers, New York.

[3] Banks, J. and Banks, C.M. (2010) Multicultural Education: Issues and Perspectives. John Wiley\& Sons, New York.

[4] Gribble, D. (1998) Real Education: Varieties of Freedom. Libertarian Education Press, Briston.

[5] Lin, Y.-S. (2011) Fostering Creativity through Education: A Conceptual Framework of Creative Pedagogy. Creative Education, 2, 149-155. http://dx.doi.org/10.4236/ce.2011.23021

[6] Neille, A.S. (1995) Summerhill School. A New View of Childhood. Martin’s Griffin, New York.

[7] Tran, L.T.B., Ho, N.T. and Hurle, R.J. (2016) Teaching for Creativity Development: Lessons from a Preliminary Study of Vietnamese and International Upper (High) Secondary School Teachers’ Perceptions and Lessons Plans. Creative 
Education, 7, 1024-1043. http://dx.doi.org/10.4236/ce.2016.77107

[8] Benbow, C.P. and Lubinski, D. (1993) Psychological Profiles of the Mathematically Talented: Some Sex Differences Supporting Their Biological Basis. In: Chiba Foundation Symposium. On the Origins and Development of High Ability. John Wiley \& Sons, New York, 44-66.

[9] Maslow, A. (1968) Towards a Psychology of Being. Van Norstrand, New York.

[10] Torrance, E.P. (1990) Torrance Tests of Creative Thinking. Scholastic Testing Service, Bensenville.

[11] Gardner, H. (2006) Multiple Intelligences: New Horizons. Basic Books, New York.

[12] Eisner, E. (2005) Arts and the Creative Mind. Yale University Press, New Haven.

[13] Freire, P. (1998) Pedagogy of the Oppressed. Rowman \& Littlefieid, Boston.

[14] Abrams, M. (2005) The Application of Critical Pedagogy to Music Teaching and Learning. Vision of Research in Music Education, 6. http://www.rider.edu/ vrme

[15] Harding, N. (2005) The Ethnography Project: A Method of Increasing Sensitivity in Teacher Candidates. http://www.edchange.org/multicultural/papers/ethnography.html

[16] United Nations Economic \& Security Council (2012) Employment Report. http://www.un.org/en/ecosoc/about/employment.html

[17] Sheffield, C. (2014) Skills-Based Education Can Help Solve the Inequality Puzzle. December, Forbes.

[18] Zhao, Y. (2012) World Class Learners: Educating Creative and Entrepreneurial Students. Corwin Press, Thousand Oaks.

[19] Bethel, D. (1994) Makiguchi: The Value Creator. Weatherhill, New York.

[20] Hsu, L. (2016) HTH Structures: Assessment. http://www.hightechhigh.org/projects/?name=HTH\%2Structures:\%Assessment

[21] Archibald, L. and Dewar, J. (2010) Creative Arts, Culture, and Healing: Building an Evidence Base. A Journal of Aboriginal and Indigenous Community Health, 8.

[22] Chen, G. (2015) Public and Private Schools. Public School Review. http://publicschoolreview.com/blog/public-school-vs-private-school

[23] Craft, A. (2003) The Limits to Creativity in Education: Dilemmas for the Educator. British Journal of Educational Studies, 51, 113-126. http://dx.doi.org/10.1111/1467-8527.t01-1-00229

\section{Submit or recommend next manuscript to SCIRP and we will provide best service for you:}

Accepting pre-submission inquiries through Email, Facebook, LinkedIn, Twitter, etc.

A wide selection of journals (inclusive of 9 subjects, more than 200 journals)

Providing 24-hour high-quality service

User-friendly online submission system

Fair and swift peer-review system

Efficient typesetting and proofreading procedure

Display of the result of downloads and visits, as well as the number of cited articles

Maximum dissemination of your research work

Submit your manuscript at: http://papersubmission.scirp.org/ 